\title{
Stability Indicating RP-HPLC Method Development and Validation for simultaneous estimation of Azelnidipine and Telmisartan in Bulk and Pharmaceutical Dosage Form
}

\section{Basava Chaitanya ${ }^{1}$, M. Ajitha ${ }^{2}$}

${ }^{1}$ M. Pharmacy Scholar, Department of Pharmaceutical Analysis, Institute of Science and Technology, JNTUH, Hyderabad

${ }^{2}$ Professor \& Head, Deputy Director of Academic Audit Cell - JNTUH \& OIE, Center for Pharmaceutical Sciences, JNTUH, Hyderabad

Received: 30-10-2021 / Revised Accepted: 27-11-2021 / Published: 02-01-2022

\begin{abstract}
A simple, Accurate, Precise method was developed for the simultaneous estimation of Azelnidipine and Telmisartan in bulk and pharmaceutical dosage form by RP- HPLC technique. Chromatogram was run through Std Denali C18 $150 \mathrm{~mm}$ x $4.6 \mathrm{~mm}, 5 \mu$. Mobile phase $0.1 \%$ OPA: Acetonitrile in the ratio of $60: 40$ and flow rate were maintained at 1.0 $\mathrm{ml} / \mathrm{min}$. Buffer used in this method was $0.1 \%$ OPA. Column temperature was set to $30^{\circ} \mathrm{C}$.Optimised wavelength selected was $242.0 \mathrm{~nm}$. Retention time of Azelnidipine and Telmisartan were found to be $2.116 \mathrm{~min} \& 3.188 \mathrm{mins}$. \%RSD of the Azelnidipine and Telmisartan System were found to be $1.6 \%$ and $1.0 \%$ respectively. \%Recovery was obtained as $100.15 \%$ and $100.20 \%$ for Azelnidipine and Telmisartan respectively. LOD and LOQ values obtained from regression equations of Azelnidipine and Telmisartan were 0.04,0.13 and $0.38,1.14$ respectively. Regression equation of Azelnidipine and Telmisartan is $\mathrm{Y}=$ $36260 \mathrm{x}+2218$ and $\mathrm{Y}=30420 \mathrm{x}+8163$. Retention times were decreased and that run time was decreased, so the method developed was simple and economical that can be adopted in regular quality control tests in industries.
\end{abstract}

Key Words: Azelnidipine, Telmisartan, RP-HPLC

\section{INTRODUCTION}

Azelnidipine is a dihydro calcium channel blocker. It has a gradual onset of action and produces a long-lasting decrease in blood pressure, with only a small increase in heart rate, unlike some other calcium channel blockers. It is currently being studied for post-ischemic stroke management. Telmisartan is an angiotensin 2 receptor antagonist
(ARBs). Recent studies suggest that it have PPAR gamma agonistic properties that could potentially confer beneficial metabolic effects. Both drugs are used in the management of Hypertension. Literature survey revealed that there were few analytical methods reported for Azelnidipine \& Telmisartan in RP-HPLC. However, an extensive literature search didn't reveal any estimation

Address for Correspondence: D. Basava Chaitanya, M. Pharmacy Scholar, Department of Pharmaceutical Analysis, Institute of Science and Technology, JNTUH, Hyderabad.

How to Cite this Article: D. Basava Chaitanya, M. Ajitha. Stability Indicating RP-HPLC Method Development and Validation for simultaneous estimation of Azelnidipine and Telmisartan in Bulk and Pharmaceutical Dosage Form. World J Pharm Sci 2022; 10(01): 121-127; https://doi.org/10.54037/WJPS.2022.100113 
method for Azelnidipine \& telmisartan in API \& Pharmaceutical dosage form. Therefore, an attempt has been made to develop and validate simple, precise, accurate economical RP-HPLC method as per ICH guidelines for the estimation of Azelnidipine\& telmisartan in Bulk and Pharmaceutical dosage form.

\section{MATERIALS AND METHODS}

Chemicals and Reagents: Acetonitrile (HPLC grade), orthophosphoric acid (HPLC grade), water (HPLC grade) was purchased from Mark (India) Ltd, Worli, Mumbai, India. All active pharmaceutical ingredients (APIs) of Azelnidipine and Telmisartan reference standards were procured from Spectrum Pharma labs, Hyderabad, India.

Instruments and Chromatographic Conditions Electronics Balance-Denver, $\mathrm{P}^{\mathrm{H}}$ meter -BVK enterprises, India, Ultrasonicator-BVK enterprises, WATERS HPLC 2695 system equipped with quaternary pumps, photo diode array detector and Auto sampler integrated with Empower 2 Software. UV-VIS spectrophotometer PG Instruments T60 with special bandwidth of $2 \mathrm{~mm}$ and $10 \mathrm{~mm}$ and matched quartz cells integrated with UV-win 6 Software was used for measuring absorbances of Azelnidipine and Telmisartan solutions. The mobile phase used was 0.1\%OPA: Acetonitrile $(60: 40)$ at a flow rate of $1.0 \mathrm{ml} / \mathrm{min}$, samples were analyzed at $242 \mathrm{~nm}$ detector wavelength and at an injection volume of $10 \mu \mathrm{L}$ using Denali C18(150 x $4.6 \mathrm{~mm}, 5 \mu \mathrm{m}$ ) with run time of $6 \mathrm{mins}$.

\section{Methods}

Diluent: Based up on the solubility of the drugs, diluent was selected, Acetonitrile and Water taken in the ratio of 50:50.

Buffer: $0.1 \%$ OPA Buffer $(1 \mathrm{ml}$ of Ortho phosphoric acid was diluted to1000 $\mathrm{ml}$ with HPLC grade water.)

Standard stock solution Preparation: Accurately weighed $20 \mathrm{mg}$ of Telmisartan, $4 \mathrm{mg}$ of azelnidipine transferred to $50 \mathrm{ml}$ volumetric flasks and $3 / 4^{\text {th }}$ of diluents was added to these flasks and sonicated for 10 mins. Flasks were made up with diluents and labeled as standard stock solution. $(400 \mu \mathrm{g} / \mathrm{ml}$ of telmisartan and $80 \mu \mathrm{g} / \mathrm{ml}$ of azelnidipine).

Standard working solution Preparation: $1 \mathrm{ml}$ from each stock solution was pipetted out and taken into a $10 \mathrm{ml}$ volumetric flask and made up with diluent. $(40 \mu \mathrm{g} / \mathrm{ml}$ of telmisartan and $8 \mu \mathrm{g} / \mathrm{ml}$ of azelnidipine).
Sample stock solution Preparation: 10 tablets were accurately weighed and the average weight equivalent to 1 tablet was transferred into a $100 \mathrm{ml}$ volumetric flask, $50 \mathrm{ml}$ of diluents was added and sonicated for $25 \mathrm{~min}$, further the volume was made up with diluent and filtered by HPLC filters. $(400 \mu \mathrm{g} / \mathrm{ml}$ of telmisartan and $80 \mu \mathrm{g} / \mathrm{ml}$ of azelnidipine).

Sample working solution preparation: $1 \mathrm{ml}$ of filtered sample stock solution was transferred to $10 \mathrm{ml}$ volumetric flask and made up with diluent. $(40 \mu \mathrm{g} / \mathrm{ml}$ of telmisartan and $8 \mu \mathrm{g} / \mathrm{ml}$ of azelnidipine).

\section{Method Validation}

As per ICH guidelines the method was validated and the parameters like Linearity, Specificity, Accuracy, Precision, Limit of Detection (LOD) and Limit of Quantitation (LOQ) were assessed.

Specificity: Checking of the interference in the optimized method. We should not find interfering peaks in blank and placebo at retention times of these drugs in this method. So this method was said to be specific.

Linearity: Stock solutions of Azelnidipine and Telmisartan is taken into 6 different volumetric flasks and diluted to $10 \mathrm{ml}$ with diluents. Linearity solutions are prepared such that $0.25,0.5,0.75,1$, $1.25,1.5 \mathrm{ml}$

Accuracy: Preparation of Standard stock solutions: Accurately weighed $20 \mathrm{mg}$ of Telmisartan, $4 \mathrm{mg}$ of Azelnidipine transferred to two separately $50 \mathrm{ml}$ and volumetric flasks, 3/4 th of diluents was added and sonicated for 10 minutes. Flasks were made up with diluents and labeled as Standard stock solution. $(400 \mu \mathrm{g} / \mathrm{ml}$ of telmisartan and $80 \mu \mathrm{g} / \mathrm{ml}$ of azelnidipine).

Preparation of $50 \%$ Spiked Solution: $0.5 \mathrm{ml}$ of sample stock solution was taken into a $10 \mathrm{ml}$ volumetric flask, to that $1.0 \mathrm{ml}$ from each standard stock solution was pipetted out, and made up to the mark with diluent.

Preparation of $100 \%$ Spiked Solution: $1.0 \mathrm{ml}$ of sample stock solution was taken into a $10 \mathrm{ml}$ volumetric flask, to that $1.0 \mathrm{ml}$ from each standard stock solution was pipetted out, and made up to the mark with diluent.

Preparation of $150 \%$ Spiked Solution: $1.5 \mathrm{ml}$ of sample stock solution was taken into a $10 \mathrm{ml}$ volumetric flask, to that $1.0 \mathrm{ml}$ from each standard stock solution was pipetted out, and made up to the mark with diluent. 
Robustness: Small deliberate changes in method like Flow rate, mobile phase ratio, and temperature are made but there were no recognized change in the result and are within range as per ICH Guide lines.

Robustness conditions like Flow minus $(0.9 \mathrm{ml} / \mathrm{min})$, Flow plus $(1.1 \mathrm{ml} / \mathrm{min})$, mobile phase minus, mobile phase plus, temperature minus $\left(25^{\circ} \mathrm{C}\right)$ and temperature plus $\left(35^{\circ} \mathrm{C}\right)$ was maintained and samples were injected in duplicate manner. System suitability parameters were not much effected and all the parameters were passed. $\%$ RSD was within thelimit.

LOD sample Preparation: $0.25 \mathrm{~m}$ each from two Standard stock solutions was pipetted out and transferred to two $10 \mathrm{ml}$ volumetric flasks and made up with diluents. From the above solution $0.1 \mathrm{ml}$ each of Telmisartan Azelnidipine solutions, were transferred to $10 \mathrm{ml}$ volumetric flasks and made up with the samediluents

LOQ sample Preparation: $0.25 \mathrm{ml}$ each from two Standard stock solution was pipetted out and transferred to two $10 \mathrm{ml}$ volumetric flasks and made up with diluents. From the above solution $0.3 \mathrm{ml}$ each of Telmisartan and Azelnidipine solutions, were transferred to $10 \mathrm{ml}$ volumetric flasks and made up with the samediluent.

System suitability parameters: The system suitability parameters were determined by preparing standard solutions of Telmisartan (40ppm) and Azelnidipine (8ppm) and the solutions were injected six times and the parameters like peak tailing, resolution and USP plate count were determined. The \% RSD for the area of six standard injections results should not be more than $2 \%$.

Assay: Assay of the marketed formulation was carried out by injecting sample corresponding to equivalent weight into HPLC system

\section{RESULTS \& DISCUSSIONS}

Optimization of Chromatographic Conditions: To develop and establish a suitable RP-HPLC method for estimation of Azelnidipine and Telmisartan in bulk and tablet dosage forms, different preliminary tests were performed and different chromatographic conditions were tested and optimized chromatographic conditions were developed which were given in Table-1.The final analysis was performed by using $0.1 \%$ Ortho phosphoric acid: Acetonitrile (60:40) at a flow rate of $1.0 \mathrm{ml} / \mathrm{min}$, samples were analyzed at $242 \mathrm{~nm}$ detector wave length and at an injection volume of $10 \mu \mathrm{L}$ using Std Denali C18 4.6 x 150mm, $5 \mu$ mwith run time of $6 \mathrm{~min}$. The proposed method was optimized to give sharp peak with good resolution and minimum tailing effect for Azelnidipine and Telmisartan, the optimized chromatogram was obtained as shown in (Figure- 3 ).

Validation: Linearity was established for Telmisartan (10-60 $\mu \mathrm{g} / \mathrm{ml}$ ) and Azelnidipine (2$12 \mu \mathrm{g} / \mathrm{ml}$ ) at six different concentrations each were injected in a duplicates and average areas were determined and linearity equations were obtained as $\mathrm{y}=36260 \mathrm{x}+2218$ for Azelnidipine and $y=30240 x+8163$ for Telmisartan. correlation coefficient $\left(\mathrm{R}^{2}\right)$ was determined as 0.999 . The Linearity calibration curves were plotted as shown in (Figure-4,5). Retention times of Telmisartan and Azelnidipine were 3.188 and $2.116 \mathrm{~min}$ where no interfering peaks in blank and placebo were found in this method. So, this method holds its specificity. Three levels of Accuracy samples 50\%, 100\%, $150 \%$ were prepared and triplicates of injections were given for each level of accuracy and mean $\%$ Recovery was obtained as $100.15 \%$ and $100.20 \%$ for azelnidipine and telmisartan. \% RSD was calculated from the corresponding peaks obtained by injecting six times a known concentration of Abiraterone was obtained as $0.20 \%$ and the $\%$ RSD for Repeatability was obtained as $0.6 \%$ and $1.2 \%$ for azelnidipine and telmisartan. Low \% RSD values indicates that the method developed was precise as shown in table. The LOD and LOQ values were evaluated based on Relative standard deviation of response and slope of the calibration curve of the two drugs. The detection limit value was obtained as0.04, 0.38 for azelnidipine and telmisartan. Quantitation limit was found to be 0.13 $\& 1.14$ for azelnidipine and telmisartan as given in (Table-4). Robustness conditions like Flow minus $(0.9 \mathrm{ml} / \mathrm{min})$, Flow plus $(1.1 \mathrm{ml} / \mathrm{min})$, mobile phase minus (55:45), mobile phase plus (65:35), temperature minus $\left(25^{\circ} \mathrm{C}\right)$ and temperature plus $\left(35^{\circ} \mathrm{C}\right)$ were maintained and samples were injected in duplicate manner (Table-5). System suitability parameters were not much affected and all the parameters were passed. \%RSD was within the limit (Table -6). Azelnidipine and Telmisartan pure drug(API) was obtained from Spectrum Pharma research solutions, combination dosage form Telma Az label claim(40/8 mg).Assay was performed with the above formulation. Average \% Assay obtained for Telmisartan and Azelnidipine was $100.22 \%$ and $100.13 \%$ and the chromatogram of standard drugs and pharmaceutical dosage forms were shown in (Figure-6,7) respectively.

Degradation Studies: Degradation studies were performed with the formulation and the degraded samples were injected. Assay of the injected samples was calculated and all the samples passed the limits of degradation (Table 8). 


\section{CONCLUSION}

Chromatographic conditions used are stationary

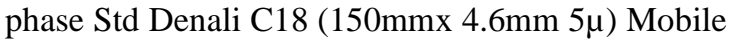
phase $0.1 \%$ OPA: Acetonitrile in the ratio of 60:40 and flow rate were maintained at $1.0 \mathrm{ml} / \mathrm{min}$, detection wave length was $242 \mathrm{~nm}$, column temperature was set to $30^{\circ} \mathrm{C}$. Conditions were finalized as optimized method. System suitability parameters were studied by injecting the standard six times and results were well under the acceptance criteria. Linearity study was carried out between $25 \%$ to $150 \%$ levels, $\mathrm{R}^{2}$ value was found to be for Telmisartan 0.9998 and Azelnidipine0.9997. Precision was found to be 1.6 and 1.0 for Azelnidipine and Telmisartan. LOD and
LOQ are0.04,0.38 and 0.13,1.14 for Azelnidipine and Telmisartan respectively. By using above method assay of marketed formulation was carried out $100.22 \%$ and $100.13 \%$ for Telmisartan respectively. Degradation studies of Azelnidipine and Telmisartan were done, in all condition's purity threshold was more than purity angle and within the acceptable range. Full length method was not performed; if it is done this method can be used for routine analysis of Azelnidipine and Telmisartan. Retention times are decreased and that run time was decreased so the method developed was simple and economical that can be adopted in regular Quality control test in Industries.<smiles>CCCc1nc2c(C)cc(-c3nc4ccccc4n3C)cc2n1Cc1ccc(-c2ccccc2C(=O)O)cc1</smiles>

Figure-1: Chemical Structure of Telmisartan<smiles>CC1=C(C(=O)OC(C)C)C(c2cccc([N+](=O)[O-])c2)C(C(=O)OC2CN(C(c3ccccc3)c3ccccc3)C2)=C(N)N1</smiles>

Figure-2: Chemical Structure of Azelnidipine

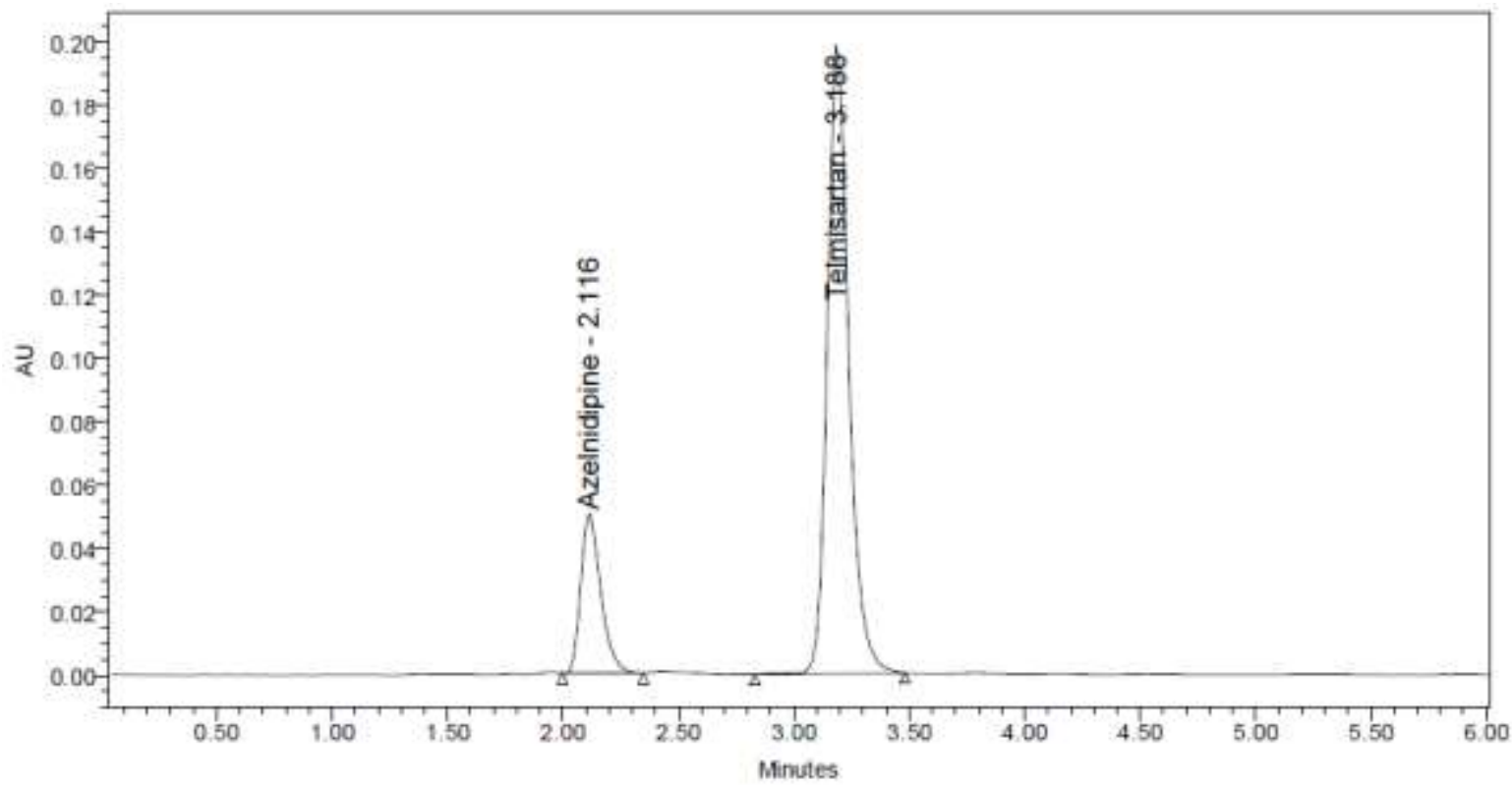

Figure-3: Optimized Chromatogram of Azelnidipine and Telmisartan 
Chaitanya and Ajitha, World J Pharm Sci 2022; 10(01): 121-127

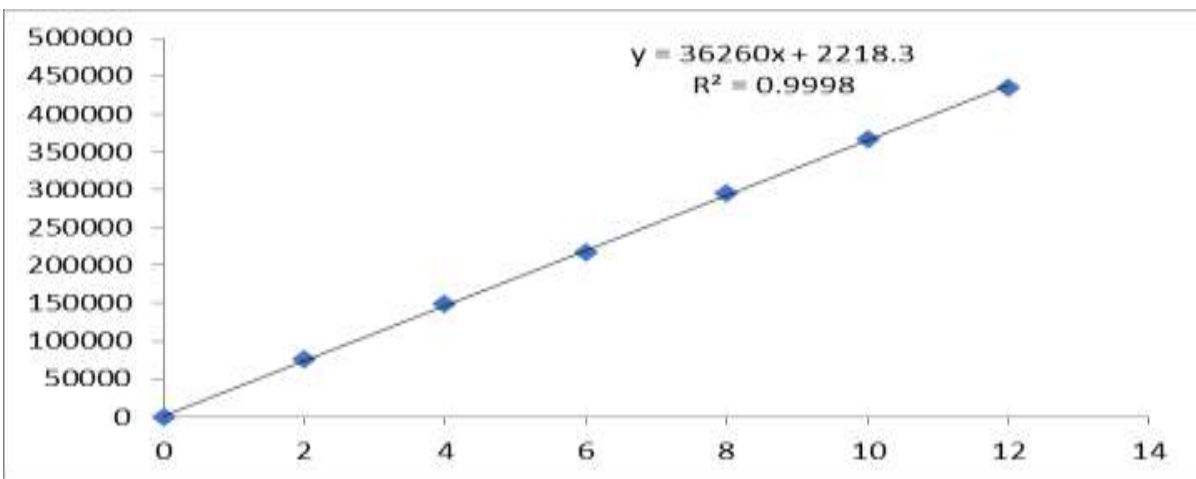

Figure -4: Linearity curve of Azelnidipine

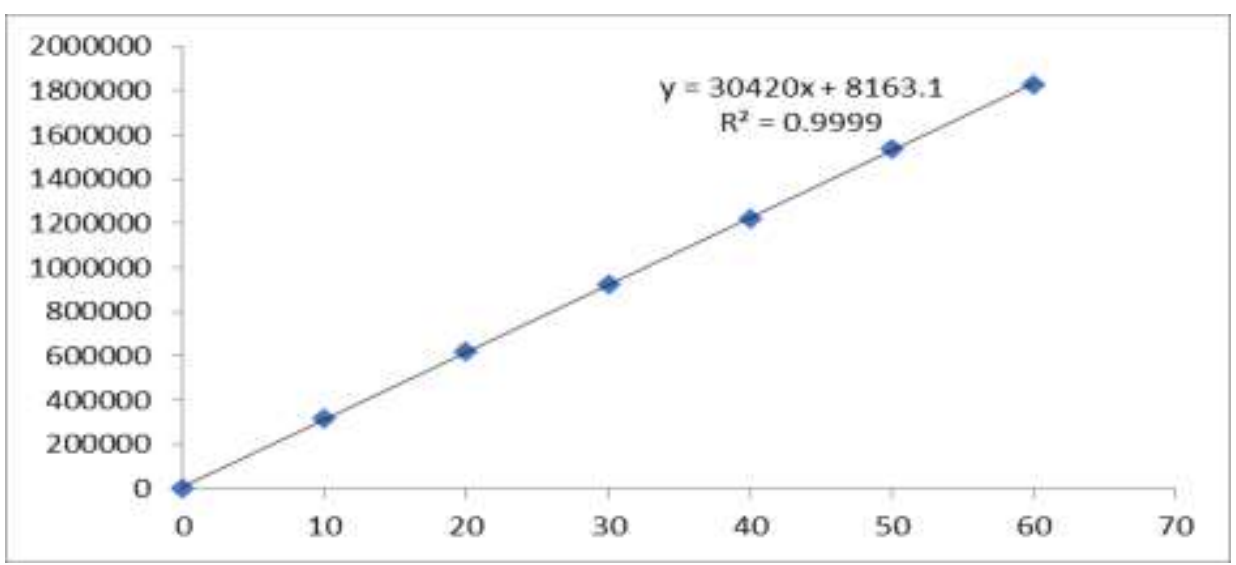

Figure -5: Linearity curve of Telmisartan

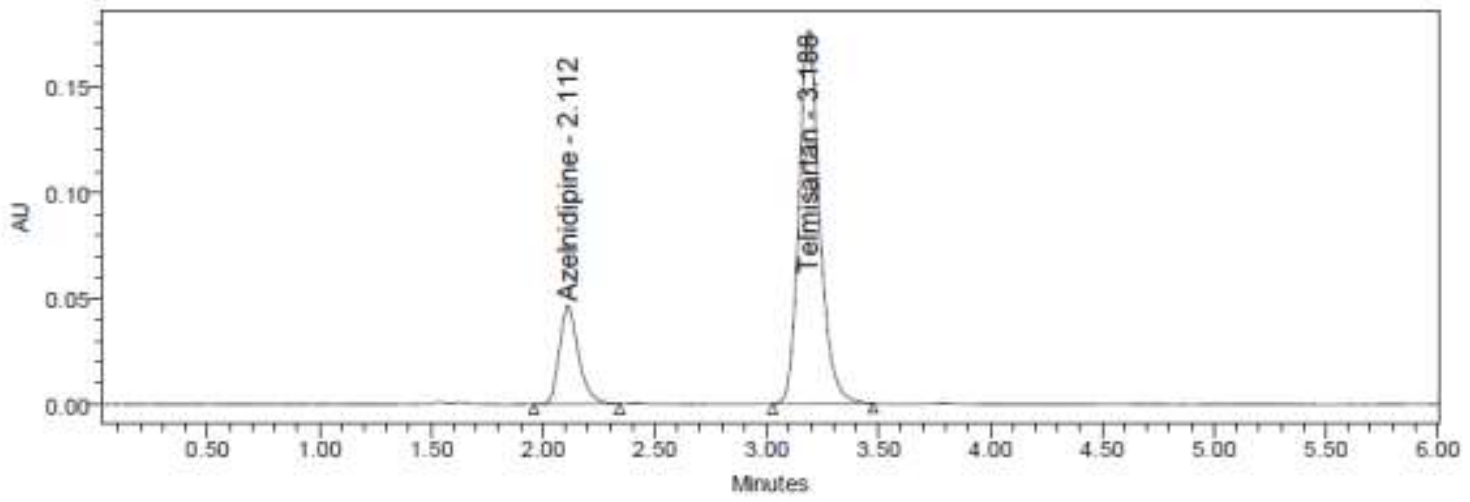

Figure -6: Standard Chromatogram of Azelnidipine and Telmisartan

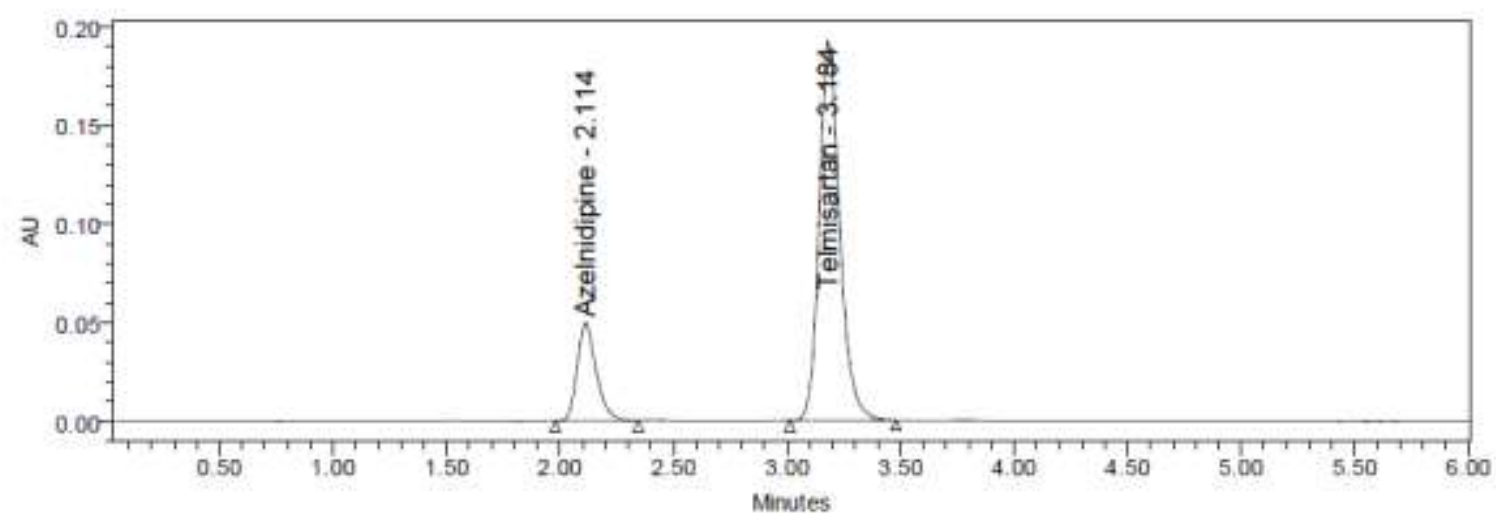

Figure -7: Sample Chromatogram of Azelnidipine and Telmisartan 
Table 1: Optimized Chromatographic Conditions

\begin{tabular}{|l|l|}
\hline Parameter & Conditions \\
\hline RP-HPLC & WATERS HPLC SYSTEM equipped with quaternary pumps with PDA detector \\
\hline Mobile Phase & $0.1 \%$ OPA :Acetonitrile $(60: 40)$ \\
\hline Flow rate & $1.0 \mathrm{ml} / \mathrm{min}$ \\
\hline Column & Denali C18(4.6x150mm,5 $\mu \mathrm{m})$ \\
\hline Injection Volume & $10 \mu \mathrm{l}$ \\
\hline Run Time & 6 mins \\
\hline Diluent & Water and Acetonitrile in ratiob 50:50 \\
\hline Retention Time & Azelnidipine-2.116 mins, Telmisartan $-3.188 \mathrm{mins}$ \\
\hline Theoretical Plates & Azelnidipine- 2740, Telmisartan- 5651 \\
\hline
\end{tabular}

Table-2: Precision Results of Azelnidipine and Telmisartan

\begin{tabular}{|l|l|l|l|l|}
\hline \multirow{2}{*}{ s.no } & Repeatability & Intermediate Precision \\
\cline { 2 - 5 } & Azelnidipine & Telmisartan & Azelnidipine & Telmisartan \\
\hline $\mathbf{1}$ & 294833 & 1249380 & 282667 & 1205161 \\
\hline $\mathbf{2}$ & 291094 & 1214505 & 290967 & 1196312 \\
\hline $\mathbf{3}$ & 290866 & 1218032 & 290137 & 1201359 \\
\hline $\mathbf{4}$ & 292949 & 1225126 & 290743 & 1202242 \\
\hline $\mathbf{5}$ & 290448 & 1245002 & 284755 & 1215203 \\
\hline $\mathbf{6}$ & 293720 & 1223169 & 283107 & 1215252 \\
\hline Mean & 292318 & 1229202 & 287063 & 1205922 \\
\hline S.D & 1777.2 & 14495.3 & 3963.2 & 7752.2 \\
\hline \%RSD & 0.6 & 1.2 & 1.4 & 0.6 \\
\hline
\end{tabular}

Table-3: Accuracy results of Azelnidipine (Drug 1) and Telmisartan( Drug 2):

\begin{tabular}{|c|c|c|c|c|c|c|c|c|}
\hline \multirow[t]{2}{*}{ \% Level } & \multicolumn{2}{|c|}{ Amount Spiked $(\mu \mathrm{g} / \mathrm{ml})$} & \multicolumn{2}{|c|}{ Amount Recovery $(\mu \mathrm{g} / \mathrm{ml})$} & \multicolumn{2}{|c|}{ \% Recover } & \multicolumn{2}{|c|}{ Mean \% Recovery } \\
\hline & Drug 1 & Drug 2 & Drug 1 & Drug 2 & Drug 1 & Drug 2 & Drug 1 & Drug 2 \\
\hline \multirow[t]{3}{*}{$\mathbf{5 0 \%}$} & 4 & 20 & 4.11 & 19.81 & 101.0 & 99.05 & \multirow{9}{*}{$100.15 \%$} & \multirow{9}{*}{$100.20 \%$} \\
\hline & 4 & 20 & 3.98 & 19.90 & 98.8 & 99.51 & & \\
\hline & 4 & 20 & 3.99 & 20.25 & 99.1 & 101.24 & & \\
\hline \multirow[t]{3}{*}{$100 \%$} & 8 & 40 & 7.99 & 40.26 & 99.9 & 100.64 & & \\
\hline & 8 & 40 & 8.1 & 39.94 & 100.9 & 99.85 & & \\
\hline & 8 & 40 & 8.0 & 40.45 & 100.1 & 101.13 & & \\
\hline \multirow[t]{3}{*}{$150 \%$} & 12 & 60 & 12.01 & 59.75 & 100.2 & 99.58 & & \\
\hline & 12 & 60 & 12.1 & 60.18 & 100.9 & 100.30 & & \\
\hline & 12 & 60 & 12.03 & 60.31 & 100.4 & 100.52 & & \\
\hline
\end{tabular}

Table-4: LOD and LOQ values of Azelnidipine and Telmisartan

\begin{tabular}{|l|l|l|}
\hline Molecule & LOD & LOQ \\
\hline Azelnidipine & 0.04 & 0.13 \\
\hline Telmisartan & 0.38 & 1.14 \\
\hline
\end{tabular}

Table-5 Robustness Data of Azelnidipine and Telmisartan

\begin{tabular}{|l|l|l|l|}
\hline S.no & Condition & \% RSD of Azelnidipine & \% RSD of Telmisartan \\
\hline $\mathbf{1}$ & Flow rate $(-) 0.9 \mathrm{ml} / \mathrm{min}$ & 0.5 & 0.4 \\
\hline $\mathbf{2}$ & Flow rate $(+) 1.1 \mathrm{ml} / \mathrm{min}$ & 0.6 & 0.4 \\
\hline $\mathbf{3}$ & Mobile phase (-) $65 \mathrm{~B}: 35 \mathrm{~A}$ & 0.2 & 0.3 \\
\hline $\mathbf{4}$ & Mobile phase $(+) 55 \mathrm{~B}: 45 \mathrm{~A}$ & 0.4 & 0.3 \\
\hline $\mathbf{5}$ & Temperature (-) $25^{\circ} \mathrm{C}$ & 0.5 & 0.5 \\
\hline $\mathbf{6}$ & Temperature $(+) 35^{\circ} \mathrm{C}$ & 0.5 & 0.2 \\
\hline
\end{tabular}


Table-6 System Suitability Parameters for Azelnidipine and Telmisartan

\begin{tabular}{|l|l|l|l|l|l|l|l|}
\hline S.no & \multicolumn{2}{|l|}{ Azelnidipine } & \multicolumn{2}{l|}{ Telmisartan } \\
\hline Inj & RT(min) & USP Plate Count & Tailing & RT(min) & USP Plate Count & Tailing & Resolution \\
\hline $\mathbf{1}$ & 2.111 & 2877 & 1.29 & 3.186 & 5830 & 1.23 & 6.6 \\
\hline $\mathbf{2}$ & 2.112 & 2879 & 1.29 & 3.188 & 5695 & 1.20 & 6.6 \\
\hline $\mathbf{3}$ & 2.112 & 2897 & 1.27 & 3.188 & 5943 & 1.21 & 6.5 \\
\hline $\mathbf{4}$ & 2.113 & 3120 & 1.28 & 3.188 & 6184 & 1.21 & 6.6 \\
\hline $\mathbf{5}$ & 2.113 & 3154 & 1.29 & 3.189 & 6291 & 1.21 & 6.6 \\
\hline $\mathbf{6}$ & 2.114 & 3014 & 1.27 & 3.189 & 6087 & 1.22 & 6.6 \\
\hline
\end{tabular}

Table-7 Assay Results ofAzelnidipine and Telmisartan

\begin{tabular}{|l|l|l|}
\hline S.no & \% Assay Azelnidipine & \%Assay Telmisartan \\
\hline $\mathbf{1}$ & 101.08 & 101.77 \\
\hline $\mathbf{2}$ & 99.80 & 98.93 \\
\hline $\mathbf{3}$ & 99.72 & 99.22 \\
\hline $\mathbf{4}$ & 100.43 & 99.80 \\
\hline $\mathbf{5}$ & 99.57 & 101.41 \\
\hline $\mathbf{6}$ & 100.70 & 99.64 \\
\hline Avg & 100.22 & 100.13 \\
\hline Stdev & 0.61 & 1.18 \\
\hline \% RSD & 0.6 & 1.18 \\
\hline
\end{tabular}

Table-8 Degradation Data forAzelnidipine and Telmisartan

\begin{tabular}{|l|l|l|l|l|}
\hline \multirow{2}{*}{$\begin{array}{l}\text { Type of } \\
\text { Degradation }\end{array}$} & Azelnidipine & Telmisartan \\
\cline { 2 - 5 } & \% Degraded & \% Recorded & \% Degraded & \% Recorded \\
\hline Acid & 6.41 & 93.59 & 6.76 & 93.24 \\
\hline Alkali & 5.01 & 94.99 & 5.33 & 94.67 \\
\hline Oxidation & 3.67 & 96.33 & 3.07 & 96.93 \\
\hline Thermal & 2.49 & 97.51 & 2.24 & 97.76 \\
\hline UV & 1.79 & 98.21 & 1.80 & 98.20 \\
\hline Water & 0.59 & 99.41 & 0.65 & 99.35 \\
\hline
\end{tabular}

\section{REFERENCES}

1. K.D.Tripathi, Essentials of Medical Pharmacology, 6th Edition, Jaypee brother's medical publishers (P) LTD, p-254-255.

2. Santosh Kumar M, Venkateshwar Rao Jupally. Development And Validation Of A Stability Indicating Rp-Hplc Method Forsimultaneous Determination Of Telmisartan And Amlodipine In Combined dosage form, Asian J Pharm Clin Res, Vol 7, Issue 1, 2014, 32-35

3. Jayvadan K. PATEL, Nilam K. PATEL. Validated Stability-Indicating RP-HPLC Method for the Simultaneous Determination of Azelnidipine and Olmesartan in Their Combined Dosage Form, Sci Pharm. 2014; 82: 541-554.

4. S.B.Wankhede-, M.R.Tajne.., RP-HPLC method for simultaneous estimation of telmisartan and hydrochlorothiazide in tablet dosage form, Indian J Pharm Sci, 2007, 69 (2): 298-300

5. Reema H. Rupareliya1 and Hitendra S. Joshi. Stability Indicating Simultaneous Validation of Telmisartan and Cilnidipine with Forced Degradation Behavior Study by RP-HPLC in Tablet Dosage Form,International Scholarly Research Notices / 2013.

6. Sutirtho Mukhopadhyay, Kiran Kadam, Laxman Sawant et al.., Simultaneous determination of related substances of telmisartan and hydrochlorothiazide in tablet dosage form by using reversed phase high performance liquid chromatographic method, J Pharm Bioallied Sci 2011Jul;3(3):375-383 